\title{
Perception of e-Learning Among Hungarian Engineering Students
}

\author{
László Berényi ${ }^{1}$, Nikolett Deutsch ${ }^{2 *}$, Bernadett Szolnoki ${ }^{1}$ and Zoltán Birkner ${ }^{3}$ \\ ${ }^{1}$ University of Miskolc, Hungary \\ $2^{2 *}$ corresponding author, Corvinus University of Budapest, Hungary \\ ${ }^{3}$ University of Pannonia, Hungary \\ szvblaci@uni-miskolc.hu \\ nikolett.deutsch@uni-corvinus.hu \\ berballa@gmail.com \\ birkner.zoltan@uni-pen.hu
}

\begin{abstract}
The success of developing e-learning is determined by curriculum quality, the availability of technological requirements and, to an even greater extent, by user response to the technology introduced in the process. Digital enhancement of education through e-learning solutions should also take the unique attributes of the targeted local region, institution, target group and field of expertise into consideration prior to implementation. The paper reports on research conducted to understand the approach of engineering students $(n=94)$ to e-learning supported by Moodle in Hungary, including computer use, evaluation of e-learning materials, systems and online exams. The research used an online questionnaire for exploring the motivation and restrictive factors of using e-learning. Survey findings confirm that e-learning functions primarily in a complementary way to traditional learning. $87.2 \%$ of the students in the sample just download the learning materials and use those offline often or regularly. $58 \%$ of them find the usefulness of e-learning materials good, but structure or aesthetics is evaluated weak or moderate by more than half of the respondents. Considering the exams, $38 \%$ of the students with previous experience in online exams prefer the traditional exams, while $25 \%$ prefer the online format. Since access to technological tools and services required for effective e-learning is available, continuous training of the teachers and tutors is necessary both for developing their everyday skills and recognizing the LCMS opportunities.
\end{abstract}

Keywords: e-learning, attitudes, computer use, ICT, information society

\section{Introduction}

The transformation of social and economic systems and the frequent changes of the labour market in recent decades brought lifelong learning to the forefront (Jarvis, 2010), and in this context, developing learning capacities became the key to successful learning (McLagan, 2017). In response to the need for adaptability to the accelerated digital world and the growing availability of info-communication tools (ICT), new education models are elaborated (Cobb, 2013). E-learning systems with their flexibility regarding time and place appeared and became widely accepted as new means to provide learning opportunities for students first entering higher education and for students reentering with the need to refresh or supplement their knowledge and acquire new skills and competencies defined by their job requirements. The spread of the internet boosted information flow and it gave e-learning a dual role: it-simultaneously acts as a place for the distribution of educational materials and as a tool of communication between teachers, tutors, and students engaged in the educational activity (Dura and Mihăilescu, 2014). Corporate and campus agendas have started to recognize e-learning as having the power to transform the performance, knowledge and skills landscape (Fatsiori, Tsimaras and Zoulias, 2018).

There is a conceptual diversity about e-learning in the literature that makes the interpretation and evaluation of the solutions complicated. Despite the fact that there is an agreement on the concept of e-learning as a teaching method (Peycheva, 2002; Kahiigi et al., 2008), there are several definitions in use. Engelbrecht (2003) or Urdan and Weggen (2000) mention the entire spectrum of electronic media as delivering tools, including internet, intranet, extranet, satellite broadcasts, audio/video, interactive TV and CD-ROMs. Meredith and Newton (2003) limit the medium to online forms, such as the internet and other web-based technologies. Recent trends show the appreciation of MOOC (Massive Open Online Course) (Barak, Watted and Haick, 2016), but these are not to be considered as equivalents of a -traditional courses (Hew and Cheung, 2014). Flexibility is a keyword in elearning development (Khan, 2007; Ollé, 2012) as is blended learning, which is a mix of traditional learning methods and e-learning elements that represent the middle path. E-learning solutions can effectively support flipped education methods (Estrada et al., 2019) or other atypical methods for student-centered learning.

E-learning and related solutions are by now heard of all over the world, yet their utilization isn't spread equally. This also means that there are several frameworks, methods and good practices of application that can be tailored to differing needs. Thus, taking into account local limiting factors, e.g., the paucity of bandwidth, scarcity 
of technical equipment, lack of expertise (Ahmed, Hussain Farid, 2018) as well as the e-learning preparedness of teachers and information technology (IT) competencies of students and the preparedness of both universities and students, are inevitable. An attractive feature of e-learning solutions is cost-efficiency. Studies investigating developing countries frequently highlight this benefit (Alamin and Elgabar, 2014; Hadullo, Oboko and Omwenga, 2017). Although cost-savings are essential for each country and university, the indirect and long-term costs of any misguided efforts may result in them exceeding their current expenses.

The acceptance of new or developed technology is a decisive condition of its application. There are several models and frameworks developed for describing the factors of success during the recent decades. Isaias and Issa (2015) summarize these models as quality evaluation models for information systems. Technology Acceptance Model (TAM) became a popular framework for exploring the attitudes and intentions of using elearning solutions. In line with other results in the field, Ibrahim et al. (2017) found that computer self-efficacy has significantly affected ease of use, while perceived ease of use significantly affects intention to use e-learning. A comprehensive analysis is difficult to feasible since the local characteristics and cross-cultural differences (Kurdi, Alshurideh and Salloum, 2020) must be kept in mind. However, sharing experience is essential both for researchers and system developers. Critical success factors of e-learning systems within a university environment should be investigated, including the teacher's understanding (Sadeck, Chigona and Cronjé, 2020).

In terms of the analysis content Selim (2017) grouped the key factors of the success and acceptance of e-learning systems into four categories: instructor, student, information technology and university support. Based on an extensive literature review, Alhabeeb and Rowley (2018) identified that key success factors of e-Learning can be divided into five main groups: instructor characteristics, student characteristics, technology infrastructure, learning systems and online learning resources, support and training. The authors also stated that most of the previous studies focused on the student perspective described by Horton (2011). The concept emphasizes that the understanding of the real needs of students can lead to developing powerful applications and making the elearning system more useful. In this regard, there is a consensus in the literature (Alhabeeb and Rowley, 2018; Lee, Yoon and Lee 2009) that students' characteristics include their experience, habits, trust and concerns regarding computer and internet usage and their attitude toward e-learning. Beyond the availability of wellstructured and easy-to-use course materials as an important determinant of students' attitudes toward elearning, enjoying the benefits of these solutions requires access to well-functioning learning systems and general IT competencies.

E-learning designed to support engineering education comes with unique characteristics and challenges. Beyond the professional skills in engineering work, a well-trained engineer must also face the rapidly changing environment, especially the accelerated information flow in professional communication. Being able to use a new CAD program, programming or simulation software no longer provides a competitive advantage in their field, and having high-level general IT competencies is a must (Pappas et al. 2019). Mallya and Srinivasan (2019) also highlight that the introduction of cloud-based mobile learning in studying an engineering subject is productive and has a positive impact on education competencies of engineering students. As Banday, Ahmed and Jan (2013) stress, engineering education traditionally follows the lecture-tutorial-laboratory paradigm and by being based on science and mathematics, needs higher level of interaction, however, more difficulties can arise in the processes of students' autonomous learning (Tawil et al. 2011). Besides the rapid uptake of ICTbased solutions, multimedia applications and software that reinforce the cognitive and procedural skills in engineering education ensure the nonlinear access to learning materials, and give the students the freedom to proceed at their own pace (Gupta, 2002) the number and accessibility of university-based virtual and remote laboratories is also growing (Banday, Ahmed and Jan 2013). Asenova and Simenov (2018) and FernándezRodríguez et al. (2013) show that the main advantages of e-learning in engineering education are 1) improving the quality of university education, 2) removing hindrances and expanding the accessibility to educating various groups of students (including those with special educational needs), 3) shaping professional competencies in the context of person-oriented flexible training, and 4) by performing lab exercises virtually, the reliance upon physical equipment, tools and supporting staff can be reduced. Cornejo et al. (2021) demonstrate that the use of e-learning platforms in engineering education can increase technological speed, allowing the creation of learning spaces on the Internet with a wide range of functionalities. Although the availability of digital and digitalized course materials, learning tools, and virtualized demonstrations via learning management systems can enhance the performance and learning experience of students, platforms and modes of asynchronous and synchronous communication should also be made available. 
Earlier research studies have attempted to explore the enormous versatility of e-learning systems and programmes and to address the key challenges and opportunities of e-learning development from the perspective of different stakeholder groups, decision levels, methodological or technical issues. According to our understanding, in order to increase the efficiency of e-learning systems and to support their adaption, it is necessary to align e-learning development goals to the expectations of targeted students as end-users. This study aims to contribute to the existing knowledge base by presenting exploratory pilot research regarding engineering students' perspectives utilizing e-learning systems in a Hungarian university. By doing so, the authors hope to stimulate interest in and provide directions for future research taking into account local circumstances and discipline-specific features in the national context.

\section{Problem formulation}

\subsection{Research goals and background}

In the relevant literature sources dealing with the critical success factors of the adaption of e-learning systems, advanced technology infrastructure, i.e. the level of connectivity, broadband and mobile network coverage, the availability of ICT tools and the understanding of users' digital and software skills are the most important prerequisites for the deployment of e-learning systems. The reports of the Hungarian Central Statistical Office (KSH, 2018; KSH, 2019) confirm that internet access was available in $86 \%$ of the households in Hungary in 2018, and $59 \%$ of all internet subscriptions were cell phone-based connections. $96 \%$ of the subscriptions were either 4 G or LTE. Data traffic shows a dynamic growth; the traffic of 64 Petabytes in 2018 Q3 is 60\% higher than that of in 2017 Q3. Furthermore, 75\% of the Hungarian population is an active computer user (the EU average is $79 \%$ ) and $77 \%$ is an active internet user (the EU average is $84 \%$ ). Online activity exceeds the EU average values in Hungary. Participation in social networks was $86 \%$ in 2018 (the EU average is 65\%); the upload of own content to the internet is performed by $54 \%$ (the EU average is $40 \%$ ). Business-oriented researches in this field also conclude that expansion of access to ICT tools is also developing, but the integration of digital technology in business remains the most challenging area (EC, 2019; Sasvári, 2013; Aureli, Ciambotti and Sasvári, 2014). Regarding the human capital dimension, only half of the population between 16 and 74 have basic digital skills, which is below the EU average (57\%), and $26 \%$ of the population has advanced internet user skills (EC, 2019).

Even though access to the internet and the trends of ICT use are encouragingly progressive, only $5 \%$ of the population is engaged in market-based e-learning services. Moreover, higher educational institutions have limited room for manoeuvre in using an e-learning system. The notions of e-learning and digital learning are not embedded in the Hungarian legal regulation - except the pressure of the Covid-19 lockdowns -, and the programme accreditation procedure of the Hungarian Accreditation Committee does not allow for national and international courses that are fully dependent on the e-learning system in state-accredited programmes. In this sense, traditional face-to-face approaches supplemented with e-learning materials and platforms, and blended learning solutions are the viable options in Hungary. Although the intention of the university is to increase the role of e-solutions to prepare the engineering students to the modern business environment which received an important boost by the Covid-19 lockdowns. The assessment of benefits and risks are not yet available, hopefully a positive experience will trigger a change in regulation.

The recent situation analysis concerning e-learning in higher education performed by the Hungarian Government in 2016 reveals that while the basic ICT infrastructure and the electronic public services of higher educational institutions are outstanding, the use of e-learning systems and digital education are developing slowly and sporadically, and the digital availability of course descriptions, requirements, contents, library aids and tests is varied in terms of quantity and quality both within and among the higher educational institutions (Hungarian Government, 2016). Although the level of use of e-learning systems by academics and by students seems to be still low and the national strategy on the development of digital education defines goals and actions at the legislative level, there is no clear guidance on the measures to be taken to support the acceleration of the adaption of e-learning systems, and the increase of user satisfaction with the e-learning systems. Thus, targeted investigations considering the unique characteristics of disciplines and programmes, e-learning systems, and the aims, needs and experience of users are needed to be able to improve the effectiveness of e-learning, and through this, to develop higher education.

This paper investigates the case of a Hungarian university (University of Miskolc) using Moodle as a learning management framework for engineering education. As in all Hungarian universities, traditional lectures and seminars are the core tools of education, and e-learning supplements those. In line with the general findings in 
the literature, the use of face-to-face approaches in most engineering courses is almost still similar to what practiced in the past, meaning that the traditional lecture-tutorial-laboratory paradigm still dominates the engineering education in the university. Improving the teaching-learning process of these courses by the introduction or the more intensive application of the platform and its services depends not only on the technology itself but also on how the students use it and their previous learning experience. Although the platform is able to support and manage teacher-student interactions, including the sharing of learning materials and the submission of homework, several problems arise from misunderstandings in communication, which, consequently, may lead to uncertainty and distrust since:

- $\quad$ students usually ask for downloadable and printable materials,

- $\quad$ after uploading a task to the LCMS (Learning Content Management System), several students also send it by e-mail or ask for an e-mail confirmation to see if the file was received.

Assuming that technical infrastructure is appropriate, it is important to investigate the students' aspects of acceptance of e-learning, including motivations and other influencing factors. Therefore, the goal of our research is to understand the habits and the motivations for using or refusing the usage of e-learning systems, materials and methods by engineering students.

In line with previous research findings, the following three hypotheses were formulated for the research:

- $\quad H 1$ : ICT tools and competencies are available in Hungary for supporting successful e-learning.

- H2: Attitudes to e-learning differ by age, gender, level of studies or work experience.

- H3: Experience gained in e-learning increases the trust in it.

\subsection{Research design}

A questionnaire with short answers and scaled ratings has been designed to investigate the main influencing factors of e-learning systems from the students' perspective. In line with the literature and the research hypotheses, the subject of investigations includes:

- computer use of engineering students,

- opinions about former IT education,

- use of e-learning materials,

- attitude towards e-learning materials,

- trust in e-learning.

Data collection is performed by an online survey managed by the EVASys Survey Automation Software. Data analysis is supported by IBM SPSS statistical software. Beyond descriptive statistics, the analysis of relationships uses cross-tabulation, ANOVA analysis and correlation analysis. A reliability test (Cronbach's Alpha) was applied where available. The test result is good (Cronbach's Alpha=0.87) for the evaluation of the digital learning materials (Section 3.4), and acceptable (Cronbach's Alpha=0.74) for the evaluation of the e-exams (Section 3.5).

The representativeness of the sample is not ensured. Although findings directly support the development of elearning solutions, the interpretation is limited due to the scope of data collection, especially the territorial limitation. Another limitation is given by the age of the respondents, students between the age of 20 and 30 years old are overrepresented, since learning is becoming increasingly common at an older age.

\section{Results}

\subsection{Sample characteristics}

The research sample consists of engineering students at the University of Miskolc, including various study programs and levels. The data collection period covers the autumn of 2018. The sample includes the responses of 94 students. The sample includes 41 female and 53 male respondents. 65 respondents are studying bachelor level programs, and 29 of them are master students. 44 students do not have any work experience. The composition of the sample by age is presented in Figure 1. 


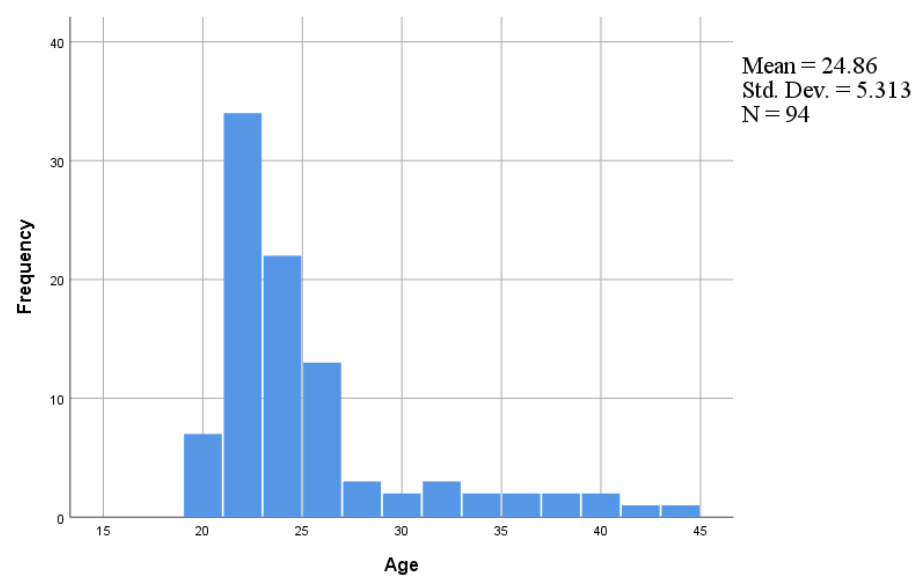

Figure 1: Distribution of age of the respondents (SPSS output)

\subsection{Computer use}

The respondents spend a considerable amount of time with ICT use. 53 of them use a desktop computer-for an average of 4.2 hours per day. A notebook is used by 71 of them, the average time spent on it is 3.5 hours per day. Smartphone use exceeds these values, 90 of 94 students use such devices, the average usage time is 5.4 hours per day. Since work obligations may influence the necessity of computer use, an ANOVA test was conducted. There is a significant difference in the use of desktop computers ( $x_{n o \_w o r k}=3.39, x_{\text {work }}=4.97 F=4.457$, sig. $=0.017)$. Although the difference is not significant, males ( 4.1 hours per day) spend more time with notebooks than females ( 2.8 hours per day), but females lead in smartphone use (5.8 hours compared to 5.0 hours per day).

Internet is mostly accessed via Wi-Fi or mobile internet. $39.4 \%$ of the respondents frequently connect to free access Wi-Fi networks, while $18.1 \%$ prefer mobile internet (even if free $\mathrm{Wi}-\mathrm{Fi}$ is available) and $4.3 \%$ completely stay away from accessing the web this way. Mobile internet access is frequently or continuously used by $79.8 \%$ of the respondents (Figure 2 ).

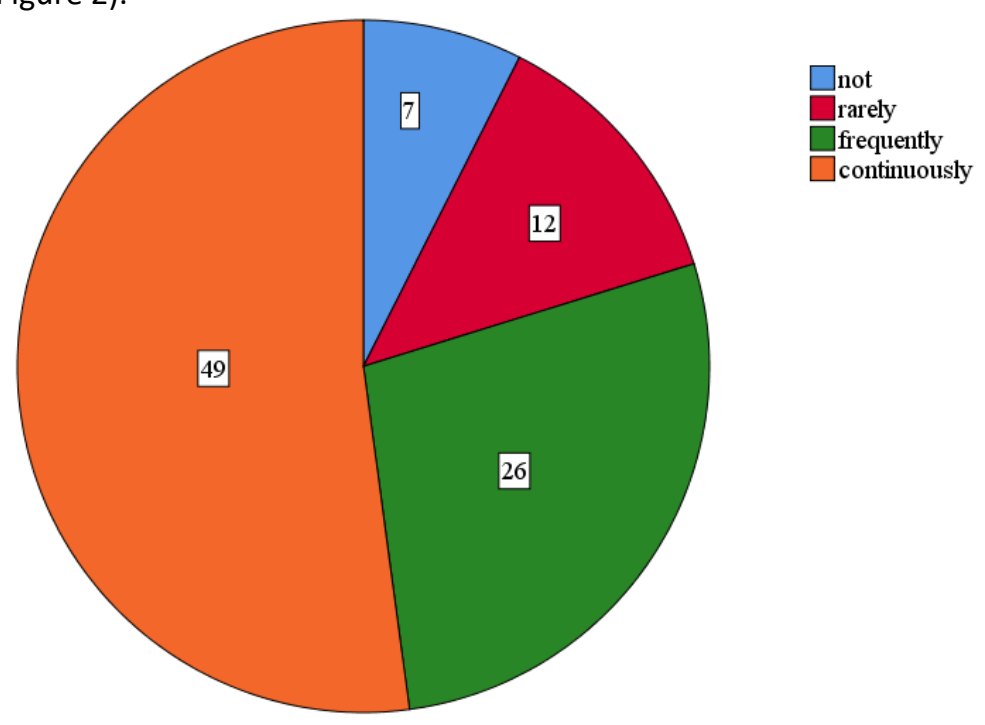

Figure 2: Use of mobile internet access

Cross-tabulation does not show differences in mobile internet or free Wi-Fi use by gender, study level or the level of work experience.

\subsection{Evaluation of IT education}

IT education is a determining factor for developing general IT competencies and has an impact on the attitude toward the use of ICTs and Internet. The content and the quality of IT courses at the elementary, secondary school level and higher education are difficult to compare due to the diverse goals, concepts and approaches, therefore the survey asks students to mark their level of satisfaction on a 6-point scale (higher value shows 
higher level of satisfaction). Based on the average values, students are moderately satisfied with the level of IT education (primary school: 3.06, secondary school: 3.54, higher education: 2.91), and are least satisfied with higher education. $43.5 \%$ is rather satisfied with the IT education in primary school, this ratio is only $30.8 \%$ in the case of higher education (Figure 3).

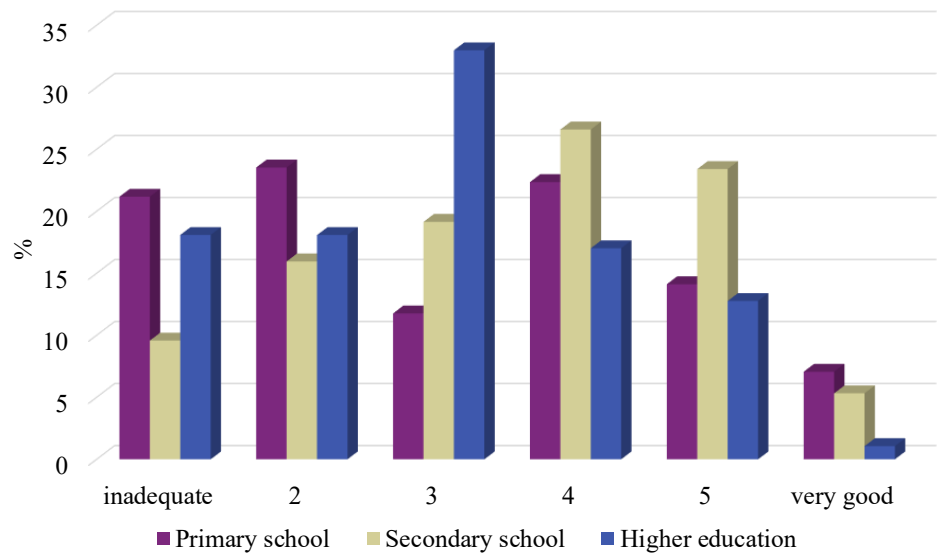

Figure 3: Evaluation of IT education

The non-parametric correlation test shows significant but weak correlations between the results on primary and secondary school levels. There is no significant correlation between the evaluations of IT education at secondary school and higher education levels (Table 1).

Table 1: Correlation between education levels about satisfaction with IT education (Spearman's rho values)

\begin{tabular}{|c|c|c|c|}
\hline & $\begin{array}{l}\text { IT education, } \\
\text { primary school }\end{array}$ & $\begin{array}{l}\text { IT education, } \\
\text { secondary school }\end{array}$ & $\begin{array}{c}\text { IT education, higher } \\
\text { education }\end{array}$ \\
\hline \multirow{3}{*}{$\begin{array}{l}\text { IT education, } \\
\text { school }\end{array}$} & 1.000 & $.483^{* *}$ & .137 \\
\hline & . & .000 & .187 \\
\hline & 94 & 94 & 94 \\
\hline \multirow{2}{*}{$\begin{array}{l}\text { IT education, secondary } \\
\text { school }\end{array}$} & $.483^{* *}$ & 1.000 & .194 \\
\hline & .000 & . & .062 \\
\hline $\mathrm{N}$ & 94 & 94 & 94 \\
\hline \multirow{2}{*}{$\begin{array}{l}\text { IT education, } \\
\text { education }\end{array}$} & .137 & .194 & 1.000 \\
\hline & .187 & .062 &. \\
\hline 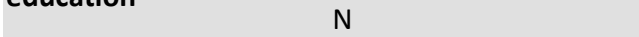 & 94 & 94 & 94 \\
\hline
\end{tabular}

**. Correlation is significant at the 0.01 level (2-tailed).

There are no significant differences in satisfaction by gender, age, study level or work experience.

\subsection{Evaluation of digital learning materials}

The research highlights two forms of digital learning materials and asks the frequency of use in two ways:

- downloadable lecture sketch and notes, slide shows,

- $\quad$ using learning content management (LCMS) systems such as Moodle.

The survey asks to evaluate the digital learning materials by structure, usefulness, aesthetics, actuality, and usability. Downloading materials and using those offline is common, $87.2 \%$ of the respondents often or regularly do this. As Figure 4 illustrates, using Moodle for supporting online learning is at lower popularity among the respondents. Most of the students consider the e-learning system as an official storage platform for course materials. 


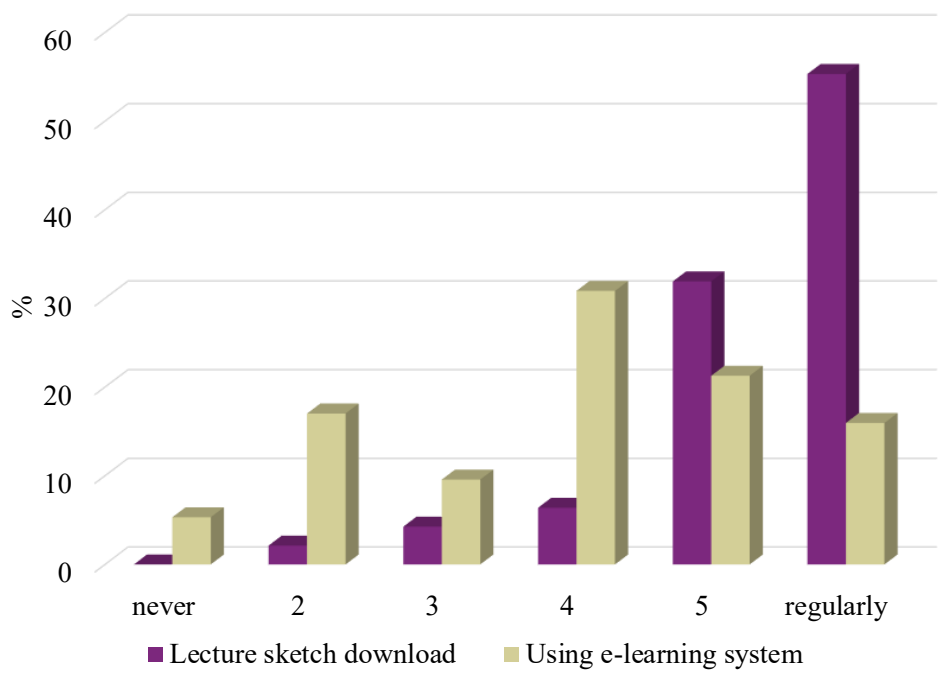

Figure 4: Using digital learning materials (frequency by the $\%$ of the respondents)

The usefulness and the usability of e-learning materials are considered rather good by about half of the students, but actuality and formal appearance are considered moderate or weak (Figure 5). Correlations between the answers show significant results. There is a strong correlation between structure and usefulness (Spearman's rho=.708 sig.=.000), structure and aesthetics (Spearman's rho $=.728$ sig. $=.000$ ). A moderate correlation is measured between aesthetics and actuality (Spearman's rho=.636 sig.=.000) as well as structure and manageability (Spearman's rho=.618 sig.=.000). All correlations are significant. These suggest that students have a general opinion about e-learning materials.

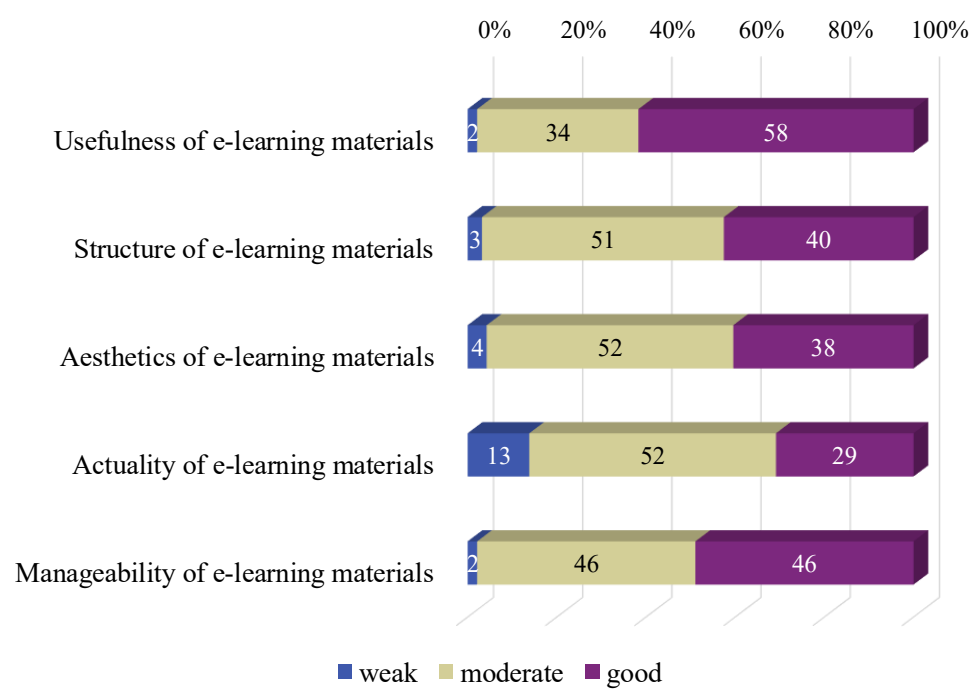

Figure 5: Evaluation of e-learning materials (number of respondents by satisfaction levels)

The $\mathrm{H} 2$ hypothesis states that satisfaction with e-learning materials differs by grouping factors of age, gender, study level, work experience or satisfaction with IT education. The statistical tests conducted are not significant; the hypothesis is rejected. Though the results suggest that younger respondents gave a better evaluation, the statistical analysis does not show significant impacts.

Correlation analysis between the ways of using digital learning materials show significant, but moderate or weak relationship (Table 2). 
Table 2: Correlation using and evaluation of digital learning materials (Spearman's rho values)

\begin{tabular}{|c|c|c|}
\hline & Using e-learning system & $\begin{array}{l}\text { Using e-learning system (of } \\
\text { other universities) }\end{array}$ \\
\hline \multirow{2}{*}{$\begin{array}{l}\text { Correlation Coefficient } \\
\text { Usefulness of e-learning } \\
{ }_{\mathrm{Sig}} \text { (2-tailed) }\end{array}$} & $.349 * *$ & .160 \\
\hline & .001 & .124 \\
\hline materials $\quad \mathrm{N}$ & 94 & 94 \\
\hline \multirow{2}{*}{ Structure of e-learning ${ }_{\text {Sig. (2-tailed) }}^{\text {Correlation Coefficient }}$} & $.266 * *$ & .066 \\
\hline & .010 & .528 \\
\hline materials $\quad \mathrm{N}$ & 94 & 94 \\
\hline \multirow{2}{*}{ Aesthetics of e-learning ${ }_{\mathrm{Sig} .}$ (2-tailed) } & $.294 * *$ & .149 \\
\hline & .004 & .153 \\
\hline materials $\quad \mathrm{N}$ & 94 & 94 \\
\hline \multirow{2}{*}{$\begin{array}{l}\text { Actuality of e-learning } \\
\text { materials }\end{array}$} & $.226^{*}$ & $.227^{*}$ \\
\hline & .029 & .028 \\
\hline materiais $\quad \mathrm{N}$ & 94 & 94 \\
\hline \multirow{2}{*}{$\begin{array}{l}\text { Manageability of } \\
\text { learning materials }\end{array}$} & .186 & .048 \\
\hline & .072 & .643 \\
\hline rearning materiais & 94 & 94 \\
\hline \multirow[b]{2}{*}{ E-exam } & .162 & .196 \\
\hline & .118 & .059 \\
\hline $\mathrm{N}$ & 94 & 94 \\
\hline \multirow{3}{*}{$\begin{array}{l}\text { Technical reliability of e- } \\
\text { exam }\end{array}$} & .183 & .154 \\
\hline & .077 & .138 \\
\hline & 94 & 94 \\
\hline \multirow{3}{*}{ Ethics of e-exam } & $.247^{*}$ & .121 \\
\hline & .016 & .247 \\
\hline & 94 & 94 \\
\hline
\end{tabular}

\subsection{E-exams}

We found that trust in completing an exam online may give relevant information about the attitudes towards elearning. $54.3 \%$ of the respondents have never made an exam online or by the support of software (jointly called e-exam), $28.7 \%$ had one e-exam and $17.0 \%$ had more.

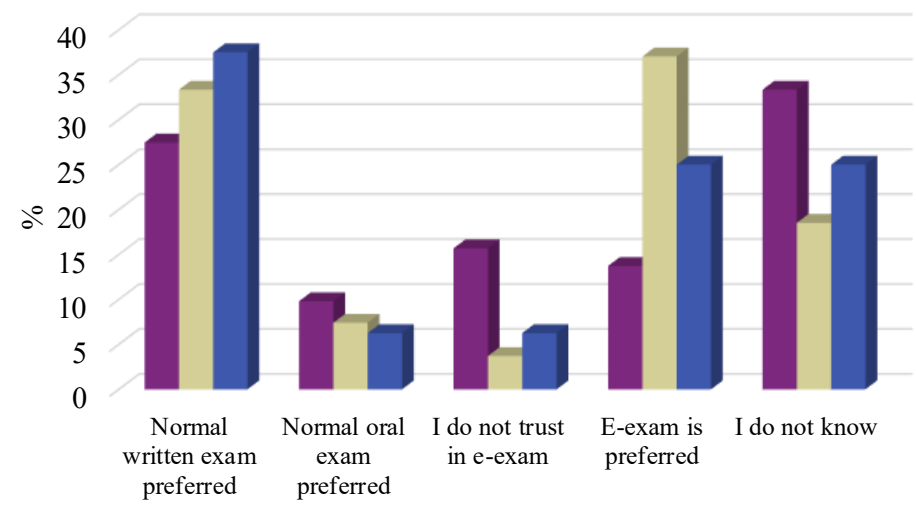

- Never had e-exam $\bowtie$ One e-exam performed $\square$ More e-exams performed

Figure 6: Preferences of e-exams or normal exams

Traditional written exams are clearly preferred by the respondents. However, it is encouraging that trust in eexams is also observable, especially if a student has participated in one earlier (Figure 6). The refuse rate of oral exams is also observable, and the proportion of uncertain respondents is high.

The analysis of variance (ANOVA) about trust in e-exams shows significant differences by technical reliability $(F=15.530$, sig. $=.000)$, ethics $(F=11.464$, sig. $=.000)$ and contribution to effective learning $(F=5.031$, sig. $=.008)$. Figure 7 summarizes the results on the trust in e-exams. 


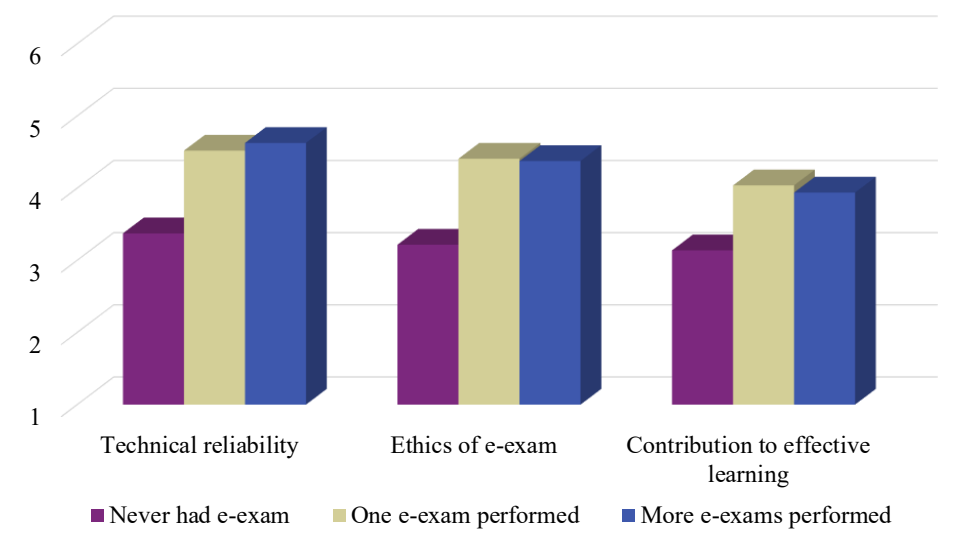

Figure 7: Trust in e-exams (mean value on a 6-point scale, higher value shows greater trust)

Statistical analysis does not confirm relevant differences by age, gender, study level, work experience or satisfaction with IT education.

\section{Discussion}

Checking the literature about the maturity of e-learning, the development of information society (Servaes, 2003; Buckland, 2017; Kovalchuk, 2020) and the intentions of higher education institutions in curriculum and methodological development (Somogyi and Szendi, 2018), e-learning seems to be the future of education. We believe that blended forms are important parts of graduate courses as well. Based on our experience, the level of utilization lags behind the opportunities, even though there are many opportunities available. According to Arasaratnam-Smith and Northcote (2017), understanding the students' sense can support the development of effective strategies towards a more digitalized and web-based higher education.

The quality of IT education at the former level is considered quite poor by the respondents; they marked mandatory and inadequate answers in the majority. Results related to the IT-based education at the higher education show considerable dissatisfaction that is a clear sign of the need for innovation.

The specific online activities of the respondents are focused on searching and downloading materials, while the utilization of learning and content management systems lags behind. It is to note that we experienced that several teachers and tutors prefer the sharing functions of the systems, while advanced options are unknown to them, which signals the need for education among teachers as well. Since a comprehensive blended learning program is more complex, including several functions of assessment and collaboration (Bentley, Selassie and Shegunshi, 2012), as Pollard and Hillage (2001) highlight, there is an urgent need for developing both teaching and learning styles to support blended learning courses. On the students' side, the main reason for this may be that they are afraid that the materials will no longer be available later. According to the teachers and tutors, the online education forced by the lockdown clearly revealed the lack of knowledge and experience in using an LCMS system including its opportunities.

Asenova and Simenov (2018) pointed out the necessity of well-structured e-learning courses. Our research shows similar results, i.e., structure, aesthetics, and actuality are critical factors. Results also suggest that students are ready to use e-learning, but disappointments in these technical aspects worsen the overall picture.

Exams integrated into the e-learning solutions are not regularly used by the educators, which influences students' opinions about e-exams. The study demonstrated, that more experience may lead to better acceptance of these exams.

Statistical tests show relevant and significant effects of various grouping factors (age, gender, level of studies) only sporadically. Although students were asked from various engineering specializations, the sample of the engineering students seems to be homogenous. An engineering student must be able to react to the challenges that occur in a rapidly changing society. This includes enhanced IT/ICT competencies even beyond the use of professional software as well as access to up-to-date knowledge in a modern form. 
According to the hypotheses of the research, the statistical analysis confirmed the following results:

- $\quad \mathrm{H} 1$ states that the availability of ICT tools and competencies is given, so the lack of these does not constitute a hindrance-to successful e-learning use. The results of the survey presented by Section 3.3 explicitly and Section 3.4 implicitly, clearly show a modern approach to ICT and active use of them. H1 can be accepted.

- $\quad$ H2 says that students' characteristics can be grouped. We conducted cross-tabulation, non-parametric correlation tests (Spearman's rho) and ANOVA, for all of the influencing factors to check the impacts of grouping factors, but no relevant ones were found. Consequently, $\mathrm{H} 2$ must be rejected.

- $\quad$ H3 is about the knowledge and experience level in e-learning. The result allows accepting partly the hypothesis; better knowledge and more experience can boost successful utilization by initiating network effects. Correlation test results, described in Section 3.5, are significant, but moderate values suggest that other factors also influence the results. According to results, the experience with e-exams lead to a higher level of trust.

\section{Conclusions}

Key findings confirm that the engineering students of the University of Miskolc are active computer users and they are online. The access to technological tools and services required to effective e-learning is granted, and the utilization of ICT allows the assumption that the students possess all necessary competencies.

Due to the widespread adoption of fast and ultrafast broadband infrastructure and the high coverage of nextgeneration access and ICT devices, the technological conditions of online learning are provided. Strategic measures and actions should be taken to improve personal attitudes. Since experience with e-learning leads to better acceptance, a diverse toolset must be applied that gradually shows the available benefits of e-learning to students.

Therefore, teachers and students must be persuaded to use e-learning more accurately. If the utilization of the LCMS system is limited to uploading and downloading lecture notes, efforts are wasted. Continuous training of the teachers and tutors is necessary to develop their everyday skills and show the LCMS opportunities.

\section{Suggestions for further research}

This study was conducted in a short period of time and investigated one sample student group numbering 94 engineering students. Although this work has some limitations as the small sample size does not provide a complete view of the current situation, it is suitable to demonstrate the importance of future research. It is expected that the paper could serve as a starting point for systemic analyses with newly introduced variables and with a larger scope, especially in Hungary, where e-learning and digital learning are not embedded in the national regulation. In-depth analysis of the knowledge related to the entire service spectrum of Moodle, the frequency and intention of use on both sides would prove critical. Exploring teachers' attitudes to e-learning platforms and the availability, quality and use of IT and e-learning trainings for teachers and students offered by the universities would be gainful to fill the research gap in the Hungarian context and identify the opportunities for improving the teaching-learning process of engineering education.

\section{Conflicts of Interest}

The authors declare no conflict of interest.

\section{References}

Ahmed, M.U., Hussain, S. and Farid, S., 2018. Factors influencing the adoption of e-learning in an open and distance learning institution of Pakistan. The Electronic Journal of e-Learning, 16(2), pp.148-158.

Alamin, H.A. and Elgabar, E.A., 2014. Success factors for adopting e-learning application in Sudan. International Journal of Soft Computing and Engineering, 3(6), pp.128-131.

Alhabeeb, A. and Rowley, J., 2018. E-learning critical success factors: Comparing perspectives from academic staff and students. Computers \& Educations, 127, pp. 1-12.

Arasaratnam-Smith, L. and Northcote M., 2017. Community in online higher education: Challenges and opportunities. The Electronic Journal of e-Learning, 15(2), pp.188-198.

Asenova, A. and Simenov, Z., 2018. Design of university e-course in electronics for future engineers. WSEAS Transactions on Advances in Engineering Education, 15(2), pp.44-48. 
Aureli, S., Ciambotti, M. and Sasvári, P.L., 2014. The Penetration of business information systems in small and mediumsized enterprises in Italy and Hungary: A Comparative Study. International Journal of Management Science and Information Technology, 11, pp.64-95.

Banday, M.T., Ahmed, M. and Jan, T.R., 2014. Applications of e-Learning in engineering education: A case study. ProcediaSocial and Behavioral Sciences, 123, pp. 406-413.

Barak, M., Watted, A. and Haick, H., 2016. Motivation to learn in massive open online courses: Examining aspects of language and social engagement. Computers \& Education, 94, pp. 49-60. 10.1016/j.compedu.2015.11.010.

Bentley, Y, Selassie, H. and Shegunshi, A., 2012. Design and evaluation of student-focused eLearning. The Electronic Journal of e-Learning, 10(1), pp.1-12.

Cobb, J., 2013. Leading the Learning Revolution: The Expert's guide to capitalizing on the exploding lifelong education market. New York: Amacom.

Cornejo, C.C., Acasiete, R. C., Quispe, V. A., Valencia, J. M. and Salazar, F. G., 2021. E-learning System Customized in the Integral Process of Teaching Learning of Engineering Students. 2021 9th International Conference on Information and Education Technology (ICIET), 2021, pp. 222-226. 10.1109/ICIET51873.2021.9419597.

Dura, C.C. and Mihăilescu, S., 2014. Designing an ANOVA experiment to estimate the impact of e-learning system upon students' performances within the University of Petrosani. WSEAS Transactions on Advances in Engineering Education, 11, pp.21-31.

European Commission, 2019. Digital Economy and Society Index (DESI) 2019 Country Report Hungary. Available at: https://ec.europa.eu/digital-single-market/en/scoreboard/hungary [Accessed: 07.05.2020].

Engelbrecht, E., 2003. A look at elLearning models: Investigating their value for developing an e-learning strategy. Progressio, 25(2), pp.38-47.

Estrada, M., Vera, G., Ruiz, R. and Arrebola, I., 2019. Flipped classroom to improve university student centered learning and academic performance. Social Sciences, 8, 315. 10.3390/socsci8110315.

Fatsiori, A., Tsimaras, D. and Zoulias, E., 2018. Vocational education and training with e-learning tools as a response to the unemployment. WSEAS Transactions on Advances in Engineering Education, 15, pp.1-6.

Fernández Rodríguez, J.C., Granados, R., Javier, J. and Muñoz, M. F., 2013. Engineering Education through eLearning technology in Spain. International Journal of Interactive Multimedia and Artificial Intelligence, 2(1), pp.46-50. 10.9781/ijimai.2013.216.

Gupta, A., 2002. Content development for elearning in engineering education. Digital Education Review, 4, pp.12-23.

Hadullo, K., Oboko, R. and Omwenga, E., 2017. A model for evaluating e-learning systems quality in higher education in developing countries. International Journal of Education and Development using Information and Communication Technology, 13(2), pp. 185-204.

Hew, K.F. and Cheung, W.S., 2014. Students' and instructors' use of massive open online courses (MOOCs): Motivations and challenges. Educational Research Review, 12, pp.45-58. 10.1016/j.edurev.2014.05.001.

Horton, W., 2011. E-learning by design. New York: Wiley.

Hungarian Government, 2016. Digital eduational strategy of Hungary. Available at: https://www.kormany.hu/download/0/4b/21000/The\%20Digital\%20Education\%20Strategy\%20of\%20Hungary.pdf. [Accessed: 07.05.2020].

Ibrahim, R., Leng, N.S., Yusoff, R.C.M., Samy, G. N., Masrom, S. and Rizman, Z.I., 2017. E-learning acceptance based on technology acceptance model (TAM). Journal of Fundamental and Applied Sciences, 9(4), pp. 871-889. 10.4314/jfas.v9i4S.50.

Isaias, P and Issa, T., 2015. High level models and methodologies for information systems. New York: Springer.

Jarvis, P., 2010. Adult Education and lifelong learning: Theory and practice. London: Routledge.

Kahiigi, E.K., Ekenberg, L., Hansson, H., Tusubira, F. F. and Danielson, M., 2008. Exploring the e-learning state of art. The Electronic Journal of e-Learning, 6(2), pp.77-88.

Kovalchuk, J., 2020. Post-Industrial Society. The Choice Between Innovation and Tradition. Cham: Palgrave Macmillan.

Központi Statisztikai Hivatal, 2019. Távközlés, Internet televízió, 2019. I. negyedév. Statisztikai Tükör, 20 June.

Központi Statisztikai Hivatal, 2018. Távközlés, Internet televízió, 2018. III. negyedév. Statisztikai Tükör, 10 Dec.

Kurdi, B.A., Alshurideh, M. and Salloum, S.A., 2020. Investigating a theoretical framework for e-learning technology acceptance. International Journal of Electrical and Computer Engineering, 10(6), pp.6484-6496. 10.11591/ijece.v10i6.pp6484-6496.

Lee, B-C., Yoon,J-O. and Lee, I., 2009. Learners' acceptance of e-learning in South Korea: Theories and results. Computers \& Education, 53, pp.1320-1329

Mallya, K. and Srinivasan, D.B., 2019. Effect of Cloud based Mobile Learning on Engineering Education. International Journal of Mechanical Engineering and Technology, 10(3), pp.614-621.

McLagan, P.A., 2017. Unstoppable you: Adopt the new learning 4.0 mindset and change your life. Alexandria: ATD Press.

Meredith, S. and Newton, B., 2003. Models of e-learning: technology promise vs. learner needs - literature review. The International Journal of Management Education, 3(3), pp.43-56. 10.3794/ijme.33.73.

Ollé, J., 2012. Virtuális környezet, virtuális oktatás. Budapest: ELTE Eötvös Kiadó.

Pappas, M.A., Demertzi, E., Papagerasimou, I., Koukianakis, L., Voukelatos, N. and Drigas, A., 2019. Cognitive-based elearning design for older adults. Social Sciences, 8(1), pp.1-18. 10.3390/socsci8010006.

Peycheva, R., 2002. Design of the university course. Sofia: University Publishing House "St. Kliment Ohridski".

Pollard, E. and Hillage, J., 2001. Exploring e-learning. Brighton: The Institute for Employment Studies. 
Sadeck, O., Chigona, A. and Cronjé, J., 2020. Understanding e-learning acceptance among teachers: A Grounded-in-Theory Approach. The Electronic Journal of e-Learning, 18(6), pp. 575-587. 10.34190/JEL.18.6.009.

Sasvári, P.L., 2013. Usage habits of business information system in Hungary. International Journal of Engineering and Innovative Technology, 2, pp.141-147.

Selim, H.M., 2017. Critical success factors for e-learning acceptance: Confirmatory factor models. Computers \& Education, 49, pp.396-413. 10.1016/j.compedu.2005.09.004.

Servaes, J. ed., 2003. The European Information Society. A reality check. Bristol: Intellect Books.

Somogyi, A. and Szendi, A. 2018. E-learning rendszerek a Miskolci Egyetemen és a könyvtári szolgáltatásokban. In: NETWORKSHOP 2018. Budapest, Hungary 4-6 April 2018. Budapest: Hungarnet.

Tawil, N.M., Ismail, N. A., Shaari, I., Osman, H., Nopiah, Z. M. and Zaharim, A., 2011. E-learning versus traditional method in teaching mathematics and statistics courses for engineering students in Universiti Kebangsaan Malaysia. In: Kongres Pengajaran dan Pembelajaran UKM 2011, Seminar Pendidikan Kejuruteraan dan Alam Bina (PeKA 2011), pp. 18-20.

Urdan, T.A. and Weggen, C.C., 2000. Corporate e-learning: exploring a new frontier. San Francisco: WR Hambrecht and Co. 